\title{
INTERCONNECTIONS BETWEEN URBAN RESIDENTIAL PLACES AND THEIR RESIDENTS IN THE PROSE OF GREEK POST-WAR NOVELIST ANDREAS FRANGIAS
}

\author{
UDC 821.14'06.09 Frangias A.
}

\section{Tamara Kostić-Pahnoglu}

University of Niš, Faculty of Philosophy, Niš, Serbia

\begin{abstract}
Andreas Frangias is one of the most important Greek post-war writers. He published four novels that cover the second half of the $20^{\text {th }}$ century. Three of the four novels take place in the urban surrounding of a big city that could be any European city of the same period, which makes them and their messages universal. The aim of this paper is to examine if and in what way the cities and the houses influence their inhabitants and if and how the inhabitants influence the houses. These interconnections obviously occupied the attention of Frangias, since even the titles of the first two novels announce them. We will examine the condition of people and their houses, as well as the whole city in three important after-war periods for Greece - immediately after WWII, after the civil war of 1945-49 and in the '80s, when the whole society was already overwhelmed with a consumerist mentality and strongly controlled by the invisible authority. It is of our interest to find out which influences are stronger and more evident. Do the psychological and emotional condition and the economical situation of the inhabitants influence their surroundings, do their surroundings influence them or are both of these true? Are these influences the same in each period? What are the messages or perhaps warnings that Frangias might have wanted to pass on to us through these interconnections?
\end{abstract}

Key words: post-war prose, space, surrounding, residential places

\section{INTRODUCTION AND AIMS}

Andreas Frangias is a Greek post-war prose writer. During the period 1955-1986 he published four novels ${ }^{1}$. The first novel, People and Houses, was published in 1955. It is a realistic novel that presents the life of people in one of Athens' poor neighbourhoods in the period immediately after the Liberation. The atmosphere reflects the ruined economy

Submitted June $9^{\text {th }} 2017$, accepted for publication November $20^{\text {th }}, 2017$

Corresponding author: Tamara Kostić-Pahnoglu

Faculty of Philosophy, Ćirila i Metodija 2, 18000 Niš, Serbia

E-mail: tamara.kostic.pahnoglu@filfak.ni.ac.rs

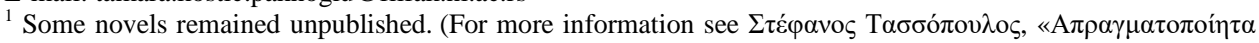

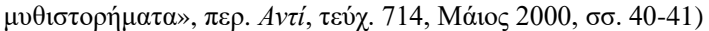


of the country and the fear for survival which replaced the fear of the occupation. The central motif of the novel is unemployment and its impact on people. The poverty and fear have a negative influence on people's psychological and emotional condition. Although the space is limited to one neighbourhood, we meet and follow many characters, none of whom can be considered protagonists. The descriptions of the surroundings contribute a lot to the outline of the characters. Most of the scenes are played inside the houses or on the street, almost never outside the neighbourhood, and the human surroundings are similar for most of the heroes - their social class strongly affects their lives and their family relationships with alienation and lack of understanding. The parallels between the houses and their inhabitants imply character traits.

Iron Gate is the second novel by Andreas Frangias, published seven years after the first. People and Houses follows people's lives immediately after the Second World War, and Iron Hate follows them after the Greek civil war, which lasted from 1945-49. The place where the events take place is again Athens, but the focus is no longer on a neighbourhood but a yard in which several families live. An iron gate separates the courtyard and its inhabitants from the outside world. While in People and Houses the main heroes are trying to find a way to survive, in IronGate, the survival issues have been replaced with so called pseudolives, as stated by Titika Dimitroulia (2002: 102). This pseudoliving is not free from economic problems, but they are no longer as acute as in the first novel (Giatromanolakis 2000: 27). New political and social conditions prevail and, even though it seems that people accept them, there is a common feeling of fear (Paganos 2000: 96). All the heroes are quite distressed by all that they have experienced in the past and by the fears of the insecure present and future. Sotiris Gakos claims correctly that "people are trapped between an external and an internal reality. Angelos is locked in the storeroom in the yard, being chased by the fear of an old conviction, while Andonis is trapped outside, chasing the chance to join the new economic conditions and trade relations" (2010: 11). In this novel there are also parallels between houses and the mental state of the inhabitants, it seems that the house follows the fate of the family that inhabits it. Although the heroes move more than in People and Houses, their movements outside of the area that is limited by the gate are often simply pointless wanderings; while the most important scenes take place mainly within the courtyard.

In the third novel, the Pestilence, Frangias describes life in a prisoner colony on an island. Although the name of the island is not mentioned anywhere, and the space and time are not specified, we can be almost completely sure that it is Makronissos, since the author had personal experiences on this island. On the one hand, there are the prisoners. The reason why these people were punished is never mentioned (although it is commonly known why people were taken to the isolated islands-prisons in Greece during the period that chronologically responds to the period when the Pestilence was written). On the other hand, there are the torturers. There is also a third category of residents - "torturers who are former prisoners and who now torture their former comrades" (Karvelis 1988:17). Since this paper examines only the urban residential places, this allegoric novel, with heroes whose residences are called "graves", will not be the subject of our consideration.

The last novel of Frangias can be considered a kind of "continuity" of the Pestilence. As pointed out by Karvelis, the "future threat to humanity, which Frangias sees in the Pestilence, in The Crowd became the reality, the present." (1988: 19). A terrible system, with absolute power not responsible to a higher authority, with laws that are not known or 
clear, rules the world of The Crowd in a similar way to how the prisoners were ruled in the Pestilence. The difference between the people in the Pestilence and in The Crowd is that in the Pestilence they knew that they were imprisoned and in The Crowd, most of them had the illusion of freedom. These anonymous people are the main protagonists of the novel. They are passively involved in life and are victims of the merciless mechanism of the system. Stavropoulou states:

People lose the sense of reality. Whatever happens in front of them can be true and cause feelings and thoughts in them. But it is possible, however, that this is only a scene from a scenario, which is repeated until the best reception is achieved. The heroes are immersed in a nightmare and idle because they cannot predict the results and consequences of any of their acts, not even the simplest everyday process (2001: 113).

Some individuals that stand out from the crowd have suspicions about what is going on around them. The system usually gives them a chance to compromise, and if they do not, they get killed. The second volume features a group of young people distinguished from the crowd. They care about each other and the contacts between them maintain warmth. Most of the people are alienated from the society they live in, from family and friends, and even from themselves. They are unable to connect the past with the present, they do not even think about the future, and cannot determine if their actions are correct. Although most heroes in The Crowd move around a lot, it seems that their movements are always limited and most of the time under supervision.

The aim of this paper is to examine if and in what way the cities and the houses influence their inhabitants and if and how the inhabitants influence the houses. These interconnections obviously occupied the attention of Frangias, since his first two novels even in their titles announce them. We will examine the condition of people and their houses, as well as the whole city in three important post-war periods for Greece - immediately after the WWII, after the civil war of 1945-49 and in the '80s, when the whole society was already overwhelmed with the consumer mentality and strongly controlled by the invisible authority. It is of our interest to find out which influences are stronger and more evident.

Do the psychological and emotional condition and the economic situation of the inhabitants influence their surroundings, do their surroundings influence them, or are both of these true? Are these influences the same in each period? What are the messages or perhaps warnings that Frangias might have wanted to pass on to us through these interconnections?

\section{DISCUSSION}

As we have seen above, three of Frangias' four novels take place in the urban surroundings of a big city that could be any European city of the same period, which makes them and their messages universal. In the first two novels Frangias mentions toponyms from Athens, and there is no question about where the events are happening. As stated by Marina Kokkinidou (2009: 99), in his first novel he does not mention the neighbourhood in which the story unfolds, but there are many small details that give us a hint: a small square, near the river, the bridge, small houses with roof tiles, courtyards with outstretched clothes and flowerpots, sometimes roofs dripping rain, some basements flooding, the dirt roads in the summer are full of dust and in the winter muddy. It could be any west side neighbourhood in Athens, right after the Second World War (Milionis 2000: 42), but definitely somewhere not 
too far away from Kokkinia, as it is mentioned at the end of the novel. In Iron Gate the situation is different, since Frangias named many more areas of Athens.

Regarding The Crowd, the author in a way leaves it to the reader to decide whether the he describes city is Athens, or any other megalopolis of the world. We assume that it is Athens, although nowhere is it mentioned by name. Kokkinidou considers it "undeniable that the town has characteristics of all modern cities" (2009: 101), while Stavropoulou claims "that space, individuals and various episodes show no special characteristics of "Hellenism", but instead, the story could have taken place anywhere in the world" (2001: 178). It is not hard to believe that the city is indeed Athens, since throughout his work Andreas Frangias did not seem particularly interested in circumstances and life outside Greece. But our opinion is that it is more important that the inhabitants of many other cities can understand and feel the atmosphere as if they are in their own country. We can completely agree with the attitude of Vangelis Hatzivasiliou that the after war misery of Athens is not at all an exclusively Greek characteristic (2000: 64).

The post war fate of Athens can be compared with any other big European city, although the Civil war that Greece was in during the period 1945-1949 surely made things a bit more difficult for Greece than for other countries that were able start recovering immediately after the WWII. In the first two novels, it is certain that the surroundings are Greek, and this encourages us to assume that, as a continuation of the first three novels, The Crowd also refers to the Greek reality. Another reason to conclude that The Crowd describes Athens is the fact that in those years it was the town in which Frangias lived, which he knew well, and which he loved and cared for enough to try to give it a prompt warning to prevent the unpleasant developments in its future. This, however, is not based on written facts. Globalization has brought most megalopolises of the world to a similar fate, and for this reason everything that applies to Athens applies to any megalopolis of the world, as stated by Stavropoulou and Kokkinidou in their studies of Frangias' work.

If we observe the work of Frangias as a whole, we can make conclusions about changes in the architecture of Athens from the period immediately after the Civil War (1945-1949) until almost the end of the twentieth century. The descriptions of the houses and the city in People and Houses are often lyrical, unlike the other three novels. Our impression is that this affinity matches with the hope that was alive in those years, but it began to fade when most people realized that their hopes were vain. Some of the examples of these descriptions are: "Our neighbourhood laid down tonight with wet clothes. It got curled up with the damp blanket of rain and wants by force to close its eyes" (1955: 241). The descriptions of the houses and their yards reflect the authentic daily life of that period. All the houses are quiet, as if they are hiding the secrets of their inhabitants well ${ }^{2}$. In People and Houses and Iron Gate, the houses are small, poor, but connected together with common courtyards, as poverty and unemployment were common to all (Kokkinidou 2009: 102). The fact that the people are limited to their poor neighbourhood in People and Houses points out the passive attitude of the inhabitants towards their fate. They are waiting for change without any active participation (Kokkinidou 2009: 100). As Papageorgiou mentions, the people live, move, suffer, hope, fall in love, get disappointed or just wander around all in the same neighbourhood (2000: 46). At the beginning of the novel all of the houses were in poor condition, especially the burnt ones. The houses burnt by bombings at the end of the war are still an open wound for the people and they do not even talk about them. Only

\footnotetext{
2 "Houses hide inside people who are discussing their issues. They all have their secrets, secretly folded" (1955: 223).
} 
one character crosses the line to these houses, Angeliki, the girl that used to live there. About his own house Argyris, who could be considered the main character, says: "Our house has become old. It has become dangerously old" (1955: 17). The inhabitants seem to be dangerously old too, if we judge by their pessimistic thoughts and the lack of initiative to change the conditions they do not like. In People and Houses, the common characteristics of all the houses are abandonment, and lack of care and order, which are elements that indicate the poverty and the problems of their inhabitants. Argyris considers it normal that his house has no pots with flowers, because the time is not right for such things. The factory is closed and that has a visible influence on the flowerpots and yards in the neighbourhood. Fear for survival was the reason that the houses were not real homes, filed with love and warmth. People felt fear lurking in the corners and they considered it wise to go inside early and keep the door well closed. The Angelikis' burnt house seemed completely destroyed, and no one could imagine that it would be inhabited again. But in the end Angeliki returns, with her mother and fiancée. Stavropoulou claims that Angeliki's forced resettlement in the burnt house implies, among others things, that the memory of the heroic and tragic past was not conclusively eliminated (2001: 131). The only permanently optimistic character is Vaso, and we are led to that conclusion by the outside view of her house, that differs completely from the other houses around: "The wall of the low house is rosy with wide stains and tangled shapes" (1955: 254).

The only live place in the neighbourhood was the tavern and the square it was on. The liveliness of the tavern is used by the author to emphasize the isolation and misery of Argyris even more. People are walking around him, the song is played from the megaphone and "he is sitting as if unemployed" (1955: 210).

The end of the novel reflects the hope for a better life that was still alive in people during those years. For some of them the better life had started to appear. It was evident first of all in their houses. The house belonging to Argyris and Georgia becomes vivid and alive again because Argyris' unemployment is over. Georgia considers it impossible that happiness could inhabit a dirty and abandoned house, saying that "now that the weather will get better, we have to paint the room and plant some flowers in our yard. At least mallows. So that it looks like an inhabited place. We will both work". The author gives quite a lot of space to the descriptions of the changes that she makes inside their house (1955: 325). Stavropoulou states that the big improvement in the relationship between Georgia and Argyris is shown by the descriptions of their house, which was put completely in order (2001: 131). But even Olga, a sick girl who is still sick at the end of the novel and probably does not have much hope, seespositive changes in her home. At the beginning of the novel her house is described as follows: "The air is eating the stones that are dried by the sun, the shutters can't be closed, neither can the door" (1955: 20). At the end the picture is different: "Today the floor tiles are strangely clean and the room found again something of its quietness" (1955: 331).

Iron Gate takes place only a few years after People and Houses. It does not have as many lyrical descriptions of the houses as in the first novel, but still the use of figures of speech is excellent, when describing the houses from the very beginning of the second half of the twentieth century. "The houses are aligned in a hurry, with small steps, shoulder to shoulder, turning their heads to the side of the rising sun, to stand straight and get in order after the messy night" (1962: 11). Most of the people are still poor and their houses reflect this poverty. Some of them reflect the deep sadness of the inhabitants. "In this house nothing reflects the dense agony that has been gathering and settling for so 
many years. This house will stand out and not look like the other. Its forehead will be wrinkled, the roof curved to one side. As a victim of war, that no one cared to break down or repair" (1962: 29). Only one house, to which Vangelia ran away to save her unborn child, fulfils its determination as a shelter (Stavropoulou 2001: 132). It is "a small house with railings loaded with greenery. A quiet decorated garden, a few stairs, the door" (1962: 395). But this house is located far away from the neighbourhood where all the other houses are.

In Iron Gate, appearance of the houses continues to follow the fate and the feelings of their residents. While she is pregnant and hoping for a happy family life, Vangelia keeps a vase full of flowers next to her, but when her relationship with Andonis got disrupted, their house became disrupted, too (1962: 325). As long as she has hope for Angelos, for his happy return, Ismini watersher flowerpots. But when she starts feeling despair for him and loses all hope, she leaves the flowers to dry. This motive is very similar to Georgia's flowers in People and Houses. For Iron Gate in comparison with People and Houses Kokkinidou states: "In Iron Gate, the horizon grows, as does the degree of active participation of the heroes in changing their fate and the circumstances of their lives. (The heroes will never gain full knowledge of the nature of the invisible power that controls their lives)" (2009: 100).

The city in Iron Gate differs from the city in People and Houses, as it has begun to thrive. Although most of the inhabitants are still busy with personal needs and problems, Andonis has the development of the city in his mind, and that is something that was completely absent from the previous novel. "This city needs better roads and many bright signs, Andonis thought" (1962: 188). Life becomes more bustling and people more tense and worried (as we will see in the last novel, this is what development necessarily brings to people). Angelos was unjustly sentenced to death, after which he went into hiding. To him, when he comes out into the world after hiding in a house for several years, everything seems more impressive, more shiny, and he noticed big changes that had happened in only a few years. "The streets filled with apartment blocks, refrigerators, radios, beautiful women and bustling people. In capitalism, everyone breaks his head in order to find out how the other one makes money" (1962: 48). We witness how this development focuses people's attention on material goods and starts causing some kind of isolation and alienation, building walls between people, even within the family. This situation undoubtedly announces the events following in The Crowd.

In the first volume of The Crowd, written around 20 years after Iron Gate, there are many descriptions of the city and even from the first description we understand that this city is very different from the one described in Iron Gate and that the environment is hostile. As Eri Stavropoulou claims, The Crowd "takes place in a modern vast metropolis, where life has become a nightmare" (2001: 111). The town is filled with traffic signs, and there are frequent references to them. Each description of the town emphasizes the hostility of the environment. "Lanterns are broken, no one changes them. The metallic river, with its wild force, makes the banks impossible to approach" (1985: 30). People at the bus stops seem to be all wearing masks with no expression. The bus suddenly passes through another street, while people are vainly waiting at the regular stop. When huge statues fall, they close the streets and the avenues. Houses are everywhere. "Where your eye falls, you see houses. Numerous windows, facades, balconies, floodlights, roof stairs, awnings, railings. Millions of people woke up today, but the landscape seems uninhabited" (1985: 56, 57). Nikos Kladis, one of the heroes that differs from the masses, considers the whole city as a body that suffers. There 
isalienation everywhere in the city: "If someone appears, he keeps the key ready in his hand, hurries to withdraw. He takes care that no one finds out anything about him, looks down, wants to remain unknown, and considers it his right. Which signs have made us so estranged?" (1985: 107).

Different threats are always close to people. Bulldozers eat the ground, and they can always get close to anyone's home. Many elements emphasize that the city is not friendly to its inhabitants. The fence that two loved ones, Thanos and Elli, encounter as an obstacle, is one of these elements. Soon, we realize that the obstacles are many, but that most of the people have learned to live with them, they have accepted compromises. It seems that they consider it inevitable to adapt to such a city and that it would be pointless to try to change anything.

But there were few people who understand the danger and the need to resist, each within his own capabilities. The false entrance door that Elli has to face while looking for a job is, in Thanos' opinion, "an alarm for everyone, much more efficient than the individual exclusion" (1985: 29). Not only are the doors false, but also entire buildings. They are made of paper and had only facades with nothing inside. The atmosphere in the city is hectic. Agis Petridis, who refuses to be in a rush, has to be punished.

Alienation prevails everywhere. People are alienated from each other even within the same family. As rightly stated by Takis Karvelis, people live in the crowd of a large city, where the decay of buildings reflects the empty inner life of people, and the incoherence of the signs reflects the chaos and the lack of regulation in that modern way of living. They live in houses-caves (1988: 23).

The novel also talks about the disease that affects some houses. Stavropoulou says that in The Crowd, the houses suffer from an unexplained disease, like a heavy infection, the cause of which no one can find. "The sick home sometimes has disturbance and sometimes burns in fever" (1985: 58). This symbolically points out the unhappiness of the inhabitants that is so vividly reflected upon them, as well as the wear and tear of the city that ultimately weights upon people. Besides, the sense of the residence as a private, personal or family space has completely vanished (Stavropoulou 2001: 132, 133). Nikos Kladis says: "A sick atmosphere affects our lives more than we understand" $(1985: 55,56)$. Tasos refuses to stay in a sick house and sleeps under a tree in the forest. The answer to the question of what the disease of the houses might be, is presented by the heroes themselves. "The infection is inside us and among us. It brings fatigue, often paralyzes and dazzles. It not only brings difficulty in breathing, but prevents us from talking, no voices are transmitted, everything is dissolved in a frazzle and you end up with the conclusion that nothing is worth your effort" (1985: 256). In the second volume, Nikos says: "Where the fear increases, Tomorrow diminishes, it is lost. The houses get sick for this reason. The fear circulates in the streets, sneaks into the houses, generates silence and frost. And the consciousness of the people melts, their words are lost, the society is sick" (1986: 359, 360). Vangelis Raftopoulos described in a few words the essential theme of The Crowd. "The facades of the houses are collapsing, the walls get sick, the streets and the entire neighbourhoods are excavated, pogrom is carried out not only against memory, but the whole human form" (2000: 24). 


\section{CONCLUSIONS}

We will now try to answer the questions we exposed at the beginning of the paper. It is obvious that there is an influence of houses and the whole city on the residents and vice versa. Stavropoulou's statement that in Frangias' work the "space is not just a lifeless scene, but plays a key role in the story case, essentially influencing the fate of his heroes" (2001: $115)$ is absolutely correct. We can conclude that the houses in all three novels follow the fate of their inhabitants. In the first two, the psychological and emotional condition of the people affects the condition of the houses, rather than the opposite. The houses are abandoned, dirty, dark, as are the yards, for as long as the heroes feel bad and live under poor and unhappy circumstances. As soon as the circumstances or their feelings change, the houses change too; they become clean, and full of light and beautiful details that reflect happiness and hope. The conditions of the inhabitants are influenced by the conditions of the whole society of that time and the condition of houses is affected by the social conditions of each chronological period. In the last novel, the role of the system, of the unseen and unfriendly authority, is very strong. It affects the whole city and its houses and it seems that this is the system's instrument for affecting the inhabitants. In The Crowd, the houses are demolished and we even witness the phenomenon that people suddenly do not have access to their houses, for which Kokkinidou states that the system prohibits access to houses, because they are carriers of the historical, collective and personal memory, and the people of The Crowd lose this (2009: 102). The system wants them to lose it, but there are a few heroes able to resist, at any cost.

The city of each novel is an intensely socially coloured space, unfriendly to the inhabitants and unsafe. In People and Houses, the lack of a friendly atmosphere is more due to the fears and survival problems that the residents suffer from constantly, while, starting with Iron Gate, a more active role is given to the system, which takes unfair decisions that some people pay for even with their lives. In The Crowd, the decisions are at first sight absurd and random, although they are actually very carefully designed to cause deep and dangerous consequences. Circulation through the city is never completely free. In People and Houses, there is an apparent freedom, but it is restricted to the boundaries of the neighbourhood. In Iron Gate the heroes cover much longer distances, but nowhere does it seem that their movement brings joy and a sense of real freedom to live their lives as they would like to. In The Crowd everything, including movement, results in an illusion. Even a long journey is something that happens without the will of the heroes. If they want to travel, they cannot, and if they get in a train, it will take them to an unwanted destination. We get the impression that everything serves the increasing of fear and unhappiness.

In the three novels examined in this paper, a period of about four decades in the second half of the twentieth century is covered. We observe that the city is changing. From the small, poor, and even burnt houses of the post-war period, the city turns into a real metropolis. Quiet picturesque neighbourhoods become soulless and noisy. The houses grow, they become blocks of apartments, but with them grows the alienation, not only among neighbours, but also within families. People, losing their freedom, lose themselves and the point of their existence is lost. With regret we can conclude that Frangias' last novel was much more prophetic than we would like it to be and it failed to warn us, probably because we were not ready to listen. As Stavropoulou claims: "Since it is written in the early 80 s, it can be considered prophetic, because many of the images of life that it is 
showing, as exaggerative as they might seem, have been verified absolutely. Indeed, if we evaluate the novel from the aspect of its connections with the nowadays reality, it proves the author's perfect insight in the problems of the present days". (2002: 112)

We cannot avoid the question of when exactly the people from People and Houses changed, the ones that had few needs and knew the real values. They wanted stable work, a roof that does not leak, a walk with the family on Sundays and a couple of warm words exchanged with friends. When exactly did they become apathetic, robots that perform the commands of others and live a life that is far from their own? What made them that way? Will there be more of those who are awake or will they all disappear? Who will win, man or the system? Are we going to live between four walls (made of paper perhaps) or in homes? Are we going to change our cities or are they going to change us? These and many more actual questions arise from the work of Frangias, and he actually offers us more questions than answers. But that was his aim, to have active and engaged readers who are able to understand their reality and change it if they do not like it.

\section{REFERENCES}

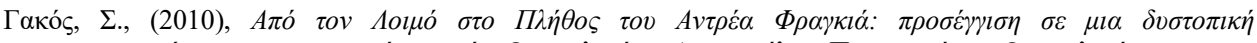

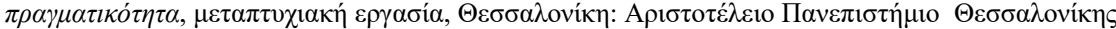

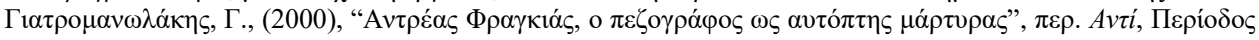

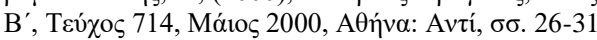

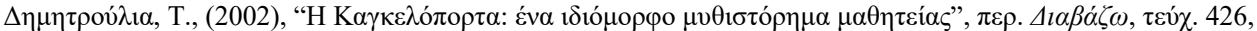

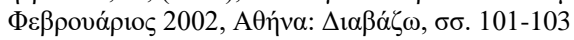

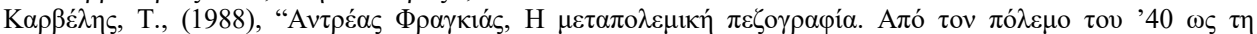

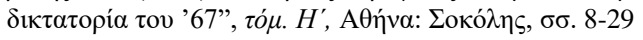

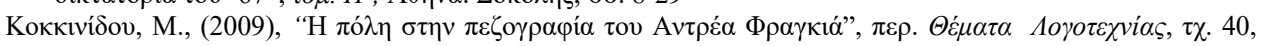

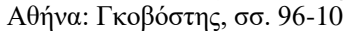

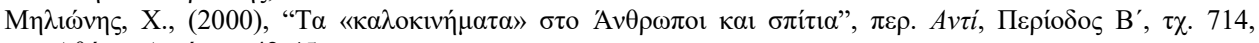

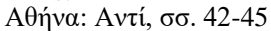

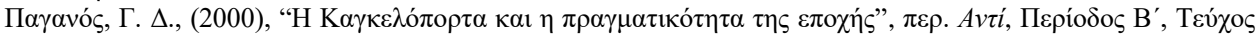

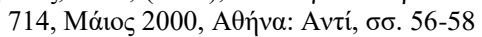

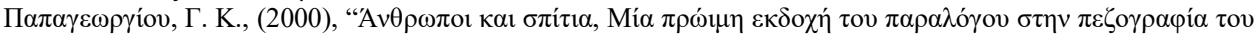

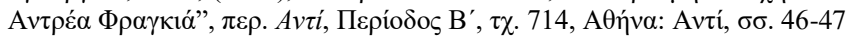

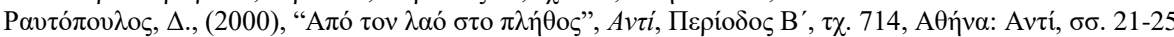

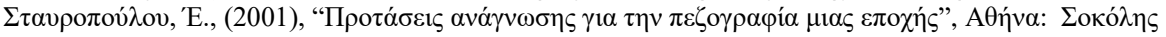

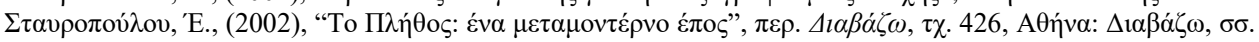
111-116

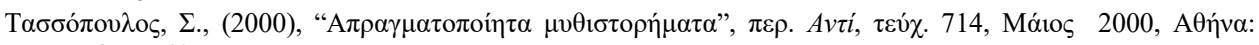

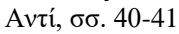

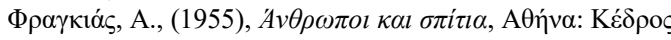

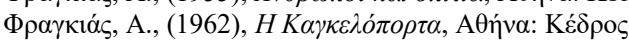

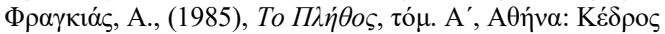

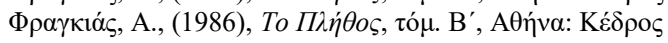

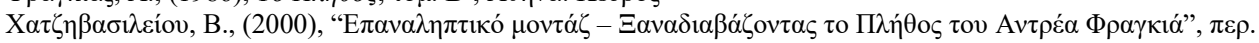

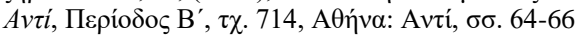




\section{MEĐUSOBNE VEZE IZMEĐU URBANIH MESTA STANOVANJA I NJIHOVIH STANOVNIKA U PROZI GRČKOG ROMANOPISCA ANDREASA FRANGJASA}

Andreas Frangjas je jedan od najznačajnijih grčkih posleratnih pisaca. Objavio je četiri romana, koji pokrivaju period druge polovine dvadesetog veka. Radnja tri od četiri romana odvija se u urbanom okruženju velikog grada, koji bi mogao biti bilo koji evropski grad iz istog vremena, što čini romane $i$ njihove poruke veoma univerzalnim. Cilj ovog rada je da ispita da li i na koji način gradovi i kuće utiču na njihove stanovnike i da li i kako stanovnici utiču na kuće. Ti međusobne veze su očigledno okupirale Frangjasovu pažnju, jer prva dva romana čak $i$ svojim naslovom ukazuju na njih. U ovom radu ispitujemo stanje ljudi i njihovih kuća, kao i celog grada u tri za Grčku važna posleratna periodaodmah nakon Drugog svetskog rata, nakon Građanskog rata 1945-1949. i tokom 80-ih, kada je celo društvo već bilo preplavljeno potrošačkim mentalitetom i čvrsto kontrolisano nevidljivom vlašću. Od interesa nam je da nađemo koji su uticaji jači i očigledniji. Da li psihološko, emocionalno i ekonomsko stanje stanovnika utiče na njihovo okruženje, nalazi se pod uticajem okruženja, ili oba? Da li su ti uticaji isti u svakom periodu? Koje su poruke, ili eventualno upozorenja, koja je Frangjas želeo da nam prenese kroz ove međusobne veze?

Ključne reči: posleratna proza, prostor, okruženje, mesta stanovanja 